\title{
Peranan Mol Rebung Dalam Meningkatkan Hasil Tanaman Bayam Cabut (Amaranthus hybridus, L.) Pada Tanah PMK
}

\author{
Nining Sri Sukasih dan Suciana Susanti \\ Fakultas Pertanian Universitas Kapuas Sintang \\ email: niningskasih@gmail.com
}

\begin{abstract}
Abstrak: Tanah PMK dikenal dengan tanah ultisol yang memiliki beberapa kekurangan seperti $\mathrm{pH}$ rendah, bahan organik rendah, unsur hara rendah serta kandungan $\mathrm{Al}$ dan $\mathrm{Fe}$ yang tinggi sehingga menghambat penyerapan hara. Agar dapat diusahakan maka pemberian MOL rebung dapat memperbaiki struktur tanah dan menambah unsur hara. Membaiknya struktur tanah dan tersedianya unsur hara menyebabkan tanaman bayam tumbuh dan berproduksi dengan baik. Penelitian ini bertujuan untuk mengetahui peranan MOL rebung dalam meningkatkan hasil bayam cabut pada tanah PMK. Penelitian ini dilakukan dengan metode percobaan lapangan. Rancangan percobaan yang digunakan adalah Rancangan Acak Kelompok dengan MOL rebung sebagai perlakuan yang terdiri dari 5 (lima) taraf dan lima ulangan yaitu: tidak diberi MOL rebung $\left(\mathrm{M}_{0}\right), 15 \mathrm{ml}$ MOL rebung $\left(\mathrm{M}_{1}\right), 30 \mathrm{ml}$ MOL rebung $\left(\mathrm{M}_{2}\right), 45 \mathrm{ml}$ MOL rebung $\left(\mathrm{M}_{3}\right)$, dan $60 \mathrm{ml}$ MOL rebung $\left(\mathrm{M}_{4}\right)$. Hasil penelitian diketahui bahwa Pemberian MOL rebung berpengaruh terhadap hasil bayam cabut pada tanah PMK, yang ditandai dengan berat segar tanaman. Pemberian $60 \mathrm{ml}$ MOL rebung menghasilkan hasil bayam cabut yang tertinggi pada tanah PMK, rata-rata 40,70 gram per tanaman.
\end{abstract}

Kata Kunci : Rebung, MOL, hasil, bayam cabut

\section{PENDAHULUAN}

Bayam cabut (Amaranthus

hybridus, L.) merupakan salah satu jenis sayuran yang banyak memberikan manfaat bagi kesehatan di antaranya dapat memberikan rasa dingin dalam perut, dapat memperlancar pencernaan dan banyak mengandung vitamin $\mathrm{A}$, vitamin $\mathrm{C}$ serta banyak mengandung garam-garam mineral yang penting seperti kalsium, fosfor, dan besi untuk mendorong pertumbuhan dan menjaga

kesehatan

(Sunaryono,2003:154). Menurut Wijaya, dkk. (2014:2), tanaman bayam dipromosikan sebagai sayuran yang berfungsi ganda yaitu sebagai pemenuhan gizi dan pendapatan ekonomi masyarakat, bayam juga mengandung riboflamin dan asam folik yang merupakan unsur penting vitamin B kompleks, asam amino dan thiamin.

$$
\text { Pada prinsipnya }
$$

membudidayakan tanaman bayam 
Peranan Mol Rebung Dalam Meningkatkan Hasil Tanaman Bayam Cabut (Amaranthus hybridus,L.) Pada Tanah PMK

tidak terlalu rumit karena dapat tumbuh disemua jenis tanah, tetapi untuk mendapatkan hasil yang tinggi hal yang harus diperhatikan adalah ketersediaan unsur hara dalam tanah. Unsur hara yang cukup hanya diperoleh pada tanah yang subur dan banyak bahan organik, kondisi tanah seperti ini tidak diperoleh pada tanah PMK karena tanah ini banyak mengandung $\mathrm{Al}$ dan $\mathrm{Fe}$ dan bahan organiknya rendah. Agar diperoleh pertumbuhan dan hasil bayam yang memiliki nilai ekonomi tinggi tanaman perlu diberi pupuk, salah satunya adalah dengan memberikan bahan organik cair yang mengandung mikroorganisme seperti Mol rebung.

MOL rebung mengandung unsur hara $\mathrm{K}, \mathrm{Mg}$ dan $\mathrm{S}$ yang sangat diperlukan oleh tanaman dalam pertumbuhan dan hasil (Susetya, 2011:1). MOL juga dapat memperkaya unsur hara tanah, berperan sebagai perbaikan sifat fisik tanah, tata ruang udara tanah, mempertinggi daya ikat tanah terhadap zat hara sehingga tidak mudah larut oleh air hujan. Pemberian MOL rebung pada tanah
PMK dirasakan sangat cocok karena bahan dasarnya adalah bahan organik yang dapat membantu menggemburkan tanah, dan menambah bahan organik tanah serta menyediakan unsur hara. Membaiknya kondisi tanah terutama fisik tanah akan mempengaruhi akar tanaman bayam dapat berkembang dengan baik dalam menyerap air dan unsur hara dalam tanah.

Tujuan penelitian ini adalah untuk mengetahui peranan MOL rebung dalam meningkatkan hasil tanaman bayam cabut pada tanah PMK

\section{METODOLOGI PENELITIAN}

\section{Metode Penelitian}

$\begin{array}{ccc} & \text { Penelitian ini dilakukan } \\ \text { dengan metode } & \text { eksperimen }\end{array}$
lapangan, menggunakan Rancangan Acak Kelompok (RAK). Faktor perlakuan dalam penelitian ini adalah MOL rebung yang terdiri dari 5 (lima) taraf dan lima ulangan. Lima taraf perlakuan yang dimaksud sebagai berikut : $\mathrm{M}_{0}=$ tidak diberi MOL rebung, $\mathrm{M}_{1}=15 \mathrm{ml} \mathrm{MOL}$ rebung, $\mathrm{M}_{2}=30 \mathrm{ml} \mathrm{MOL}$ rebung 
Peranan Mol Rebung Dalam Meningkatkan Hasil Tanaman Bayam Cabut (Amaranthus hybridus, L.) Pada Tanah PMK

, $\mathrm{M}_{3}=45 \mathrm{ml}$ MOL rebung dan $\mathrm{M}_{4}=$ $60 \mathrm{ml}$ MOL rebung

Jumlah keseluruhan pengamatan adalah yaitu 5 taraf MOL rebung x 5 ulangan $x 16$ tanaman $=400$ tanaman percobaan. Tanaman pengamatan diambil 4 tanaman dari tiap petakan percobaan, sehingga didapat 5 taraf MOL rebung $\times 5$ ulangan $\times 4$ tanaman $=$ 100 tanaman pengamatan.

\section{Bahan dan Alat Penelitian}

Bahan-bahan yang digunakan dalam penelitian ini adalah : benih bayam, rebung, gulamerah, air beras, furadan $3 \mathrm{G}$, pupuk kandang kotoran ayam. Alat-alat yang digunakan dalam penelitian ini adalah parang dan cangkul, ember plastik, saringan , handsprayer, kamera, alat tulis, timbangan digital, jarum suntik printer, penggaris .

\section{Waktu dan tempat penelitia}

Penelitian ini dilaksanakan pada Desember sampai Maret 2019. Tempat pelaksanaan penelitian adalah Desa Baning Kota Kecamatan Sintang Kabupaten Sintang.

\section{HASIL DAN PEMBAHASAN}

\section{Hasil Penelitian}

\section{Berat Segar}

Rerata pengamatan terhadap berat segar tanaman bayam cabut dapat dilihat pada Tabel 1.

Tabel 1.Reratap engamatan MOL Rebung Terhadap Berat Segar Per Tanaman(g)

\begin{tabular}{cccccccc}
\hline \multirow{2}{*}{ Perlakuan } & \multicolumn{5}{c}{ Ulangan } & \multirow{2}{*}{ Jumlah } & Rerata \\
\cline { 2 - 6 } & I & II & III & IV & V & & \\
\hline M $_{\mathbf{0}}$ & 18,25 & 24,25 & 32,25 & 22,00 & 28,50 & $\mathbf{1 2 5 , 2 5}$ & $\mathbf{2 5 , 0 5}$ \\
$\mathbf{M}_{\mathbf{1}}$ & 18,00 & 21,00 & 27,25 & 23,50 & 39,25 & $\mathbf{1 2 9 , 0 0}$ & $\mathbf{2 5 , 8 0}$ \\
$\mathbf{M}_{\mathbf{2}}$ & 20,50 & 19,00 & 37,50 & 26,25 & 35,00 & $\mathbf{1 3 8 , 2 5}$ & $\mathbf{2 7 , 6 5}$ \\
$\mathbf{M}_{\mathbf{3}}$ & 26,25 & 26,75 & 48,25 & 26,50 & 29,00 & $\mathbf{1 5 6 , 7 5}$ & $\mathbf{3 1 , 3 5}$ \\
$\mathbf{M}_{\mathbf{4}}$ & 43,75 & 47,50 & 36,00 & 40,00 & 36,25 & $\mathbf{2 0 3 , 5 0}$ & $\mathbf{4 0 , 7 0}$ \\
\hline Total & $\mathbf{1 2 6 , 7 5}$ & $\mathbf{1 3 8 , 5 0}$ & $\mathbf{1 8 1 , 2 5}$ & $\mathbf{1 3 8 , 2 5}$ & $\mathbf{1 6 8 , 0 0}$ & $\mathbf{7 5 2 , 7 5}$ & $\mathbf{3 0 , 1 1}$ \\
\hline
\end{tabular}

Sumber: Data pengamatan, 2018. 
Peranan Mol Rebung Dalam Meningkatkan Hasil Tanaman Bayam Cabut (Amaranthus hybridus,L.) Pada Tanah PMK

Data hasil pengamatan tersebut selanjutnya dianalisa dengan menggunakan Analisa Sidik Ragam yang disajikan pada Tabel 2.

Tabel 2. Analisis Sidik Ragam MOL Rebung terhadap Berat Segar Per Tanaman (g)

\begin{tabular}{|c|c|c|c|c|c|c|}
\hline \multirow{2}{*}{ SK } & \multirow{2}{*}{ DB } & \multirow{2}{*}{ JK } & \multirow{2}{*}{ KT } & \multirow{2}{*}{$\underset{\text { hitung }}{\text { F }}$} & \multicolumn{2}{|c|}{ F tabel } \\
\hline & & & & & 0,05 & $\mathbf{0 , 0 1}$ \\
\hline Ulangan & 4 & 421,98 & 105,50 & $2,38^{\text {tn }}$ & 3,01 & 4,77 \\
\hline Perlakuan & 4 & 819,58 & 204,90 & $4,63^{*}$ & 3,01 & 4,77 \\
\hline Galat & 16 & 708,82 & 44,30 & & & \\
\hline Total & 24 & 1950,39 & & $\mathbf{k k}=$ & $22,11 \%$ & \\
\hline
\end{tabular}

Sumber: Hasil analisis data, 2018.

Keterangan: $\mathrm{tn}=$ pengaruh tidak nyata pada taraf $95 \%$

$* \quad=$ pengaruh nyata pada taraf $95 \%$

Hasil analisis data Langkah selanjutnya dilakukan Uji menunjukkan bahwa perlakuan MOL BNJ yang hasil perhitungannya rebung berpengaruh sangat nyata ditampilkan dalam Tabel 3.

terhadap berat segar tanaman.

Tabel 3. Uji BNJ MOL Rebung Terhadap Berat Segar PerTanaman (g)

\begin{tabular}{|c|c|c|c|c|c|}
\hline Perlakuan & Rerata & \multicolumn{4}{|c|}{ Beda } \\
\hline $\mathbf{M}_{0}$ & $25,05 \mathrm{a}$ & - & & & \\
\hline $\mathbf{M}_{1}$ & $25,80 \mathrm{a}$ & $0,75^{\mathrm{tn}}$ & - & & \\
\hline $\mathbf{M}_{2}$ & $27,65 a b$ & $2,60^{\operatorname{tn}}$ & $1,85^{\mathrm{tn}}$ & - & \\
\hline $\mathbf{M}_{3}$ & $31,35 \mathrm{~b}$ & $6,30^{*}$ & $5,55^{*}$ & $3,70^{\mathrm{tn}}$ & - \\
\hline $\mathbf{M}_{4}$ & $40,70 \mathrm{c}$ & $15,65^{* *}$ & $14,90^{* *}$ & $13,05^{* *}$ & $9,35^{* * *}$ \\
\hline BNJ 0,05 = & 5,39 & & 3NJ 0,01 & 6,91 & \\
\hline
\end{tabular}

Sumber: Hasilanalisis data, 2018.

Keterangan: tn = beda tidak nyata pada taraf $95 \%$

* = beda nyata pada taraf kepercayaan $95 \%$

** = beda nyata pada taraf $99 \%$

Nilai yang tertera dalam tabel yang disertai dengan huruf sama menunjukkan tidak beda nyata pada taraf kepercayaan $95 \%$ 
Peranan Mol Rebung Dalam Meningkatkan Hasil Tanaman Bayam Cabut (Amaranthus hybridus,L.) Pada Tanah PMK

Hasi luji BNJ seperti yang terlihat dalamTabel 3, diketahui bahwa berat segar tanaman mengikuti taraf pemberian MOL Rebung. Semakin tinggi dosis diberikan maka semakin tinggi juga berat segar tanaman bayam cabut.

\section{Pembahasan}

Hasil analisa data diketahui bahwa pemberian MOL rebung berpengaruh nyata terhadap berat segar tanaman. Menurut Salisbury dan Ros (2005) berat basah merupakan total berat tanaman yang merupakan hasil aktivitas metabolik tanaman.

Pemberian MOL rebung 60 ml menghasilkan berat tanaman tertinggi disebabkan karena kandungan mikroorganisme dan senyawa fitohormon yang terdapat didalam MOL rebung. Menurut Mulyono (2015) MOL rebung bambu mengandung senyawa giberelin untuk pertumbuhan vegetatif. Giberelin memiliki fungsi utama yaitu mendorong perkembangan biji, perkembangan kuncup dan perpanjangan batang dan pertumbuhan daun mendorong pembungaan mempengaruhi pertumbuhan dan diferensiasi akar. Sari, dkk (dalam Sukasih) menyatakan bahwa salah satu zat pengatur tumbuh yang dihasilkan oleh mikroba dalam MOL adalah auksin dan sitokinin. Sitokinin berfungsi merangsang pembelahan sel, merangsang pembentukan tunas pada batang maupun pada kalus, menghambat efek dominansi apikal, dan mempercepat pertumbuhan memanjang. Bertambahnya jumlah sel pada tanaman pada percobaan ini diduga menyebabkan berat tanaman menjadi lebih baik dibandingkan dengan tanaman yang tidak diberi MOL rebung. Wattimena (1988), auksin akan meningkatkan kandungan zat organic dan anorganik di dalam sel. Selanjutnya zat-zat tersebut akan diubah menjadi protein, asam nukleat, polisakarida, dan molekul kompleks lainnya. Senyawa-senyawa tersebut akan membentuk jaringan dan organ, dengan demikian berat basah tanaman meningkat.

$$
\text { Meningkatnya berat segar }
$$

tanaman sebagai akibat dari 
Peranan Mol Rebung Dalam Meningkatkan Hasil Tanaman Bayam Cabut (Amaranthus hybridus,L.) Pada Tanah PMK

pengaruh pemberian MOL rebung juga diduga karena ketersediaan dan serapan unsure hara yang diperlukan oleh tanaman menjadi tersedia seperti karbohidrat, protein dan lipida. Senyawa-senyawa tersebut berperan dalam pembentukan organorgan tanaman. Seperti dikemukakan oleh Harjadi (1995) bahwa hasil metabolisme (karbohidrat, protein dan lipida) digunakan tanaman untuk keperluan pembentukan dan pembesaran sel tanaman. Selanjutnya dijelaskan oleh Dwidjoseputro (1992) bahwa tanaman akan tumbuh subur dan memberikan hasil yang baik jika unsure hara yang dibutuhkannya tersedia dalam jumlah cukup dan seimbang.

\section{KESIMPULAN DANSARAN}

\section{Kesimpulan}

Hasil analisa data pada percobaan ini diambil kesimpulan sebagai berikut:

1. Pemberian MOL rebung berpengaruh tidak nyata terhadap pertumbuhan, tetapi berpengaruh nyata terhadap hasil bayam cabut pada tanah PMK, yang ditandai dengan berat segar tanaman.
2. Pemberian $60 \mathrm{ml} \mathrm{MOL}$ rebung menghasilkan hasil bayam cabut yang tertinggi pada tanah PMK, rata-rata 40,70 gram per tanaman.

\section{Saran}

Berdasarkan hasil penelitian ini disarankan untuk:

1. Memberikan MOL rebung dalam budidaya bayam cabut karena pertumbuhan dan hasil meningkat yang terlihat pada berat segar tanaman.

2. Meningkatkan hasil bayam cabut pada tanah PMK dapat diberikan $60 \mathrm{ml}$ MOL rebung.

\section{DAFTAR PUSTAKA}

Arinong AR, Lasiwua CD. 2011. Aplikasi Pupuk Organik Cair Terhadap Pertumbuhan dan Produksi Tanaman Sawi. Jurnal Agrisistem 7(1): 4754.

Ariyanto. 2008. Analisis Tata Niaga Sayuran Bayam. Institut Pertanian Bogor, Bogor.

Badan Pusat Statistik Kalimantan Barat. 2017. Kalimantan Barat Dalam Angka Tahun 2017. Pontianak: BPS Kalimantan Barat.

Bandini. 2002. Budidaya Bayam. Jakarta: Penebar Swadaya. 
Peranan Mol Rebung Dalam Meningkatkan Hasil Tanaman Bayam Cabut (Amaranthus hybridus,L.) Pada Tanah PMK

Bucman, H.O., Brady, N.C. terjemahan Soegiman. 1982. Ilmu Tanah. Jakarta: Bhatara Karya Aksara.

Dinas Pertanian Kabupaten Jombang. 2010. Panduan Pembuatan Mikroorganisme Lokal. Dinas Pertanian Kabupaten Jombang.

Dwidjoseputro, D. 1992. Pengantar Fisiologi Tumbuhan. Jakarta: PT. Gramedia Pustaka Utama.

Fazria, M. A. 2011. Pengukuran Zat Besi Dalam Bayam Merah Dan Suplemen Penambah Darah Serta Penanganan Terhadap Peningkatan Hemoglobin Dan Zat Besi Dalam Darah. Universitas Indonesia, Depok.

Gadner, F.P., R.B. Pearce., dan R.L. Mitchell. 1991. Fisiologi Tanaman Budidaya. Diterjemahkan oleh Herawati
Susilo dan Subiyanto. Jakarta: Universitas Indonesia Press.

Hadisoeganda, A. W. W. 1996. Bayam sayuran penyangga petani di Indonesia. Monograft No. 4, Bandung.

Hardjadi. S.S. 1991. Pengantar Agronomi. Jakarta: Gramedia Pustaka Utama.

Hardjowigeno, S. 1992. Klasifikasi Tanah dan Pedogenesis. Jakarta: Akademika Presindo.

Hardjowigeno, S. 2003. Ilmu Tanah. Jakarta: Akademika Presindo.

Lindung. 2015. Teknologi Mikroorganisme EM4 dan MOL. Jambi: Balai Pelatihan Penyuluhan Jambi.

Lingga, P. 1995. Petunjuk Penggunaan Pupuk. Jakarta: Penerbit Swadaya. 